\title{
A Novel Design for a Solar PV-Wind Hybrid System to Improvise Renewable Energy Harnessing - a theoretical study on Indian Subcontinent
}

\author{
Parag Nijhawan ${ }^{\# 1}$, Amandeep Singh Oberoi ${ }^{\# 2}$, Baljit Singh ${ }^{\# 3}$ \\ ${ }^{\# 1}$ Electrical and Instrumentation Engineering Department, \\ Thapar Institute of Engineering and Technology, Patiala, India. \\ \#2 Mechanical Engineering Department, Thapar Institute of Engineering and Technology, Patiala, India. \\ ${ }^{\# 3}$ Faculty of Mechanical Engineering, Universiti Teknologi MARA, Shah Alam, Selangor, Malaysia. \\ ${ }^{1}$ parag.nijhawan@rediffmail.com \\ 2oberoi@thapar.edu \\ ${ }^{3}$ bs_dhillon@hotmail.com
}

\begin{abstract}
Inherently variable nature of renewable sources of energy such as solar and wind, are incapable of meeting continuous supply demand. Combining solar photovoltaic (PV) and wind power could offer a feasible solution to the problem of continuous power supply, particularly in those geographical locations where both resources are available in abundance. The present paper investigates the solar and wind energy potential in Indian sub-continent. The feasibility of harnessing renewable energy per sq. meter of land (i.e. energy density) from a combined solar PV-Wind hybrid system in the selected location - Jaisalmer in Rajasthan, is reported. The solar irradiance and wind velocity data for the last three decades for the selected site is collected using PVsyst software. A novel design of PV-wind hybrid system is proposed to gauge the better utilization of the existing space, productivity enhancement, and energy/m2 harnessed from the utilized land. The proposed system would pave a way forward towards developing a more sustainable, effective and rugged hybrid renewable energy systems that could cater the energy needs of the Indian sub-continent and similar geographical locations.
\end{abstract}

Keyword - solar energy, wind energy, renewable energy harnessing, hybrid system.

\section{INTRODUCTION}

Most of the human activities are energy dependent and therefore, it is worthwhile mentioning that energy is an inherent and the most essential part required for survival of mankind [1]. Contradictory to this, one of the most crucial challenges facing the mankind is the energy crisis [2]. Moreover, for energy needs people are still relying on continuously depleting conventional fossil fuels which emit harmful green house gases, when burnt [3]. In lieu to this, the researchers are bound to explore alternate sources of energy that are capable of meeting the continuous power supply demand, are environmental friendly, and could contribute to a sustainable society. One of the solutions to the mentioned problem is shifting to renewable sources of energy [4-6].

Most of the renewable sources of energy are inherently variable in nature and hence, is incapable of meeting the continuous power supply demand. Therefore, all renewable energy power generation/conversion systems are backed by energy storage devices such as batteries [7-9]. However, combination of more than one available renewable energy source could yield better results in terms of energy harnessing efficiency and energy production per unit space occupied. In this context, a novel design of Solar PV-wind hybrid system is proposed in which an array of solar PV is installed around the periphery of the stem of a horizontal-axis wind turbine. To investigate the feasibility of the proposed system a detailed theoretical study is conducted and simulation is carried out in PVsyst software by implementing the system on a selected site viz. Jaisalmer, Rajasthan in India. The fixed input parameters of the selected site are inserted to obtain the results in terms of power generation and its variance through-out the year. 


\section{SYSTEM DESCRIPTION}

The proposed hybrid system consist of a solar PV module mounted across the periphery of the stem/tower of a horizontal-axis wind turbine, a battery bank, converter circuit, controller, and other accessories as shown in Fig. 1. The PV array is mounted on the stem at an angle of $-30^{\circ}$ with respect to the horizontal to avoid the shadow and hence, attain the maximum incident solar radiation for a particular point of time. The PV array is placed around the stem of the wind turbine at a vertical distance of $30-40 \mathrm{~m}$ from the base measure from the inner edge of the mounted system wherein, the average total height of stem is around $110-120 \mathrm{~m}$.

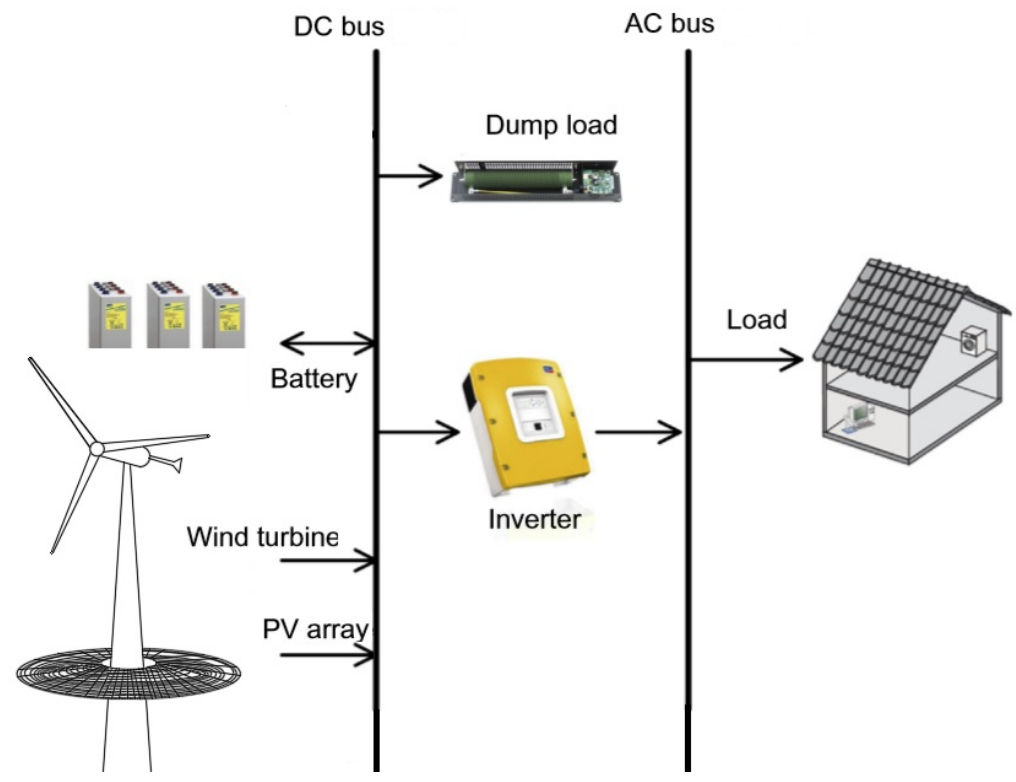

Fig. 1. Schematic of the proposed solar PV-wind hybrid system

The output of solar PV array is fed to the DC bus. The conditioned output from the wind turbine system is also fed to the same bus. When energy from either of the systems is available, it drives the electronic load. The excess energy generated during peak wind or solar or both, gets stored in the battery bank to meet the power demand during off-peak generation. The converter circuit converts the DC power into AC to meet the load demand. The DC loads are directly fed from the DC bus. Although the proposed system runs similar to the conventional PV-wind hybrid systems however, the new design offers additional advantages discussed in the succeeding section.

\section{Proposed Hybrid Solar PV-Wind System}

Generally, a conceptual PV-wind hybrid system work as independent units connected to the DC bus which lowers the overall energy harness output per $\mathrm{m}^{2}$ of the land occupied. Therefore, a novel design of PV-wind hybrid system is proposed to gauge the better utilization of the existing space, productivity enhancement, and energy $/ \mathrm{m}^{2}$ harnessed from the utilized land. The efficiency of any given solar PV module depends on the following factors:

1. The operating temperature of solar cell.

2. The cooling arrangement for the cell, and

3. The time of exposure to the sun radiation incident on the cell.

All the above factors are cater by the proposed system as the rotating wind turbine blades would generate a draft of air that will aid-in keeping the low operating temperature of solar cell. Moreover, the tilted (angled) design of solar PV array would avoid shadow and hence, provide maximum time and intensity of sunlight exposure thereby generating more power.

\section{Site ANALYSIS}

It is viable to install the proposed hybrid system at particular sites where both solar and wind energy is available in abundance. One such site is Jaisalmer in Rajasthan state of India located at 26.9157 latitude and 70.9083 longitude respectively. The solar irradiance and wind velocity data for the last three decades for the selected site is collected using PVsyst software. The input parameters inserted in the PVsyst are given in Fig. 2. The angle of tilt considered here is the angle at which the solar PV array is mounted on the wind turbine stem with respect to the horizontal. 


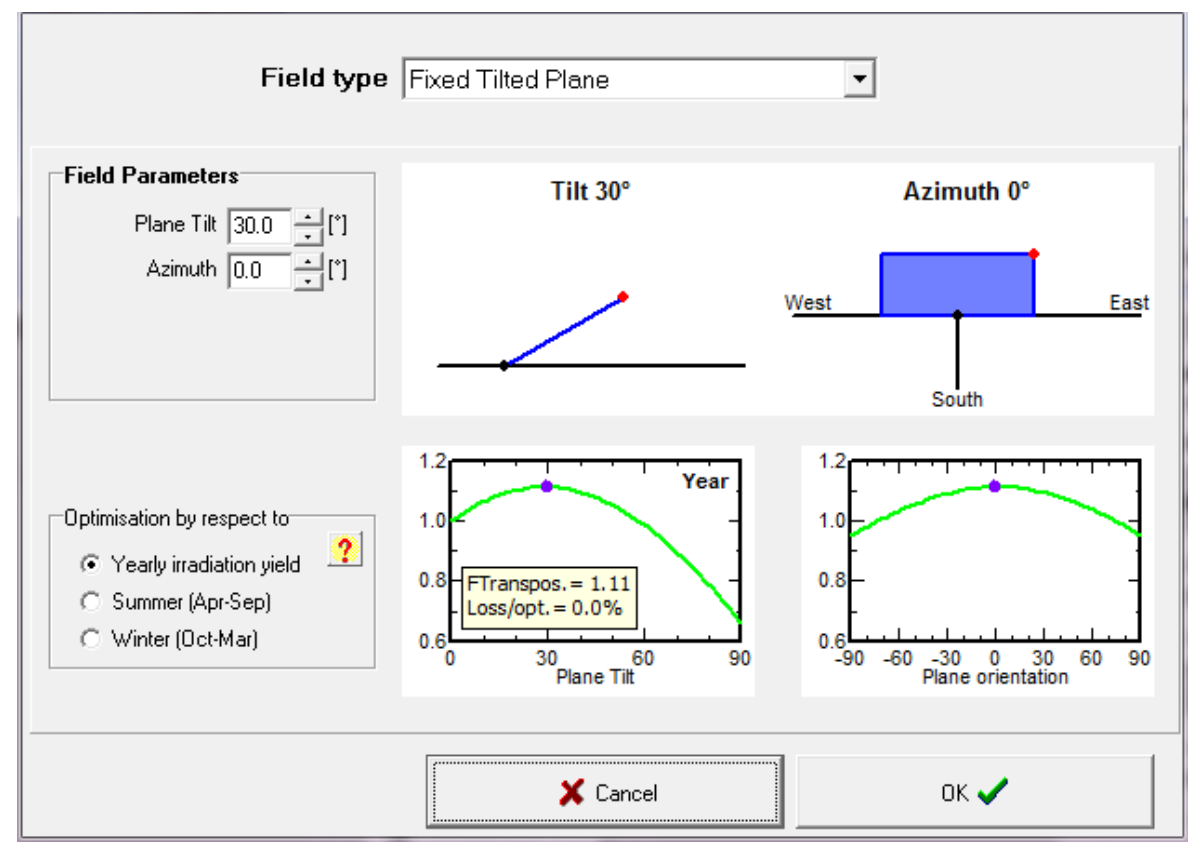

Fig. 2. Snapshot of input parameters inserted in PVsyst for site analysis

The maximum power point (MPP) curve was obtained from the PVsyst software against the inserted input parameters for the proposed PV array around the stem of the wind turbine. The obtained curve helped assessing the maximum power generation capability of the proposed PV system and found to be equal to $3 \mathrm{~kW}$ at STC, $2.8 \mathrm{KWdc}$ at $50^{\circ} \mathrm{C}$, and $2.1 \mathrm{kWac}$. It also accounts the overload loss of $36.7 \mathrm{kWh}$. The results allowed estimating the power sizing and hence inverter output distribution system. Fig. 3 shows the obtained MPP curve and inverter output distribution for the selected site i.e. Jaisalmer.

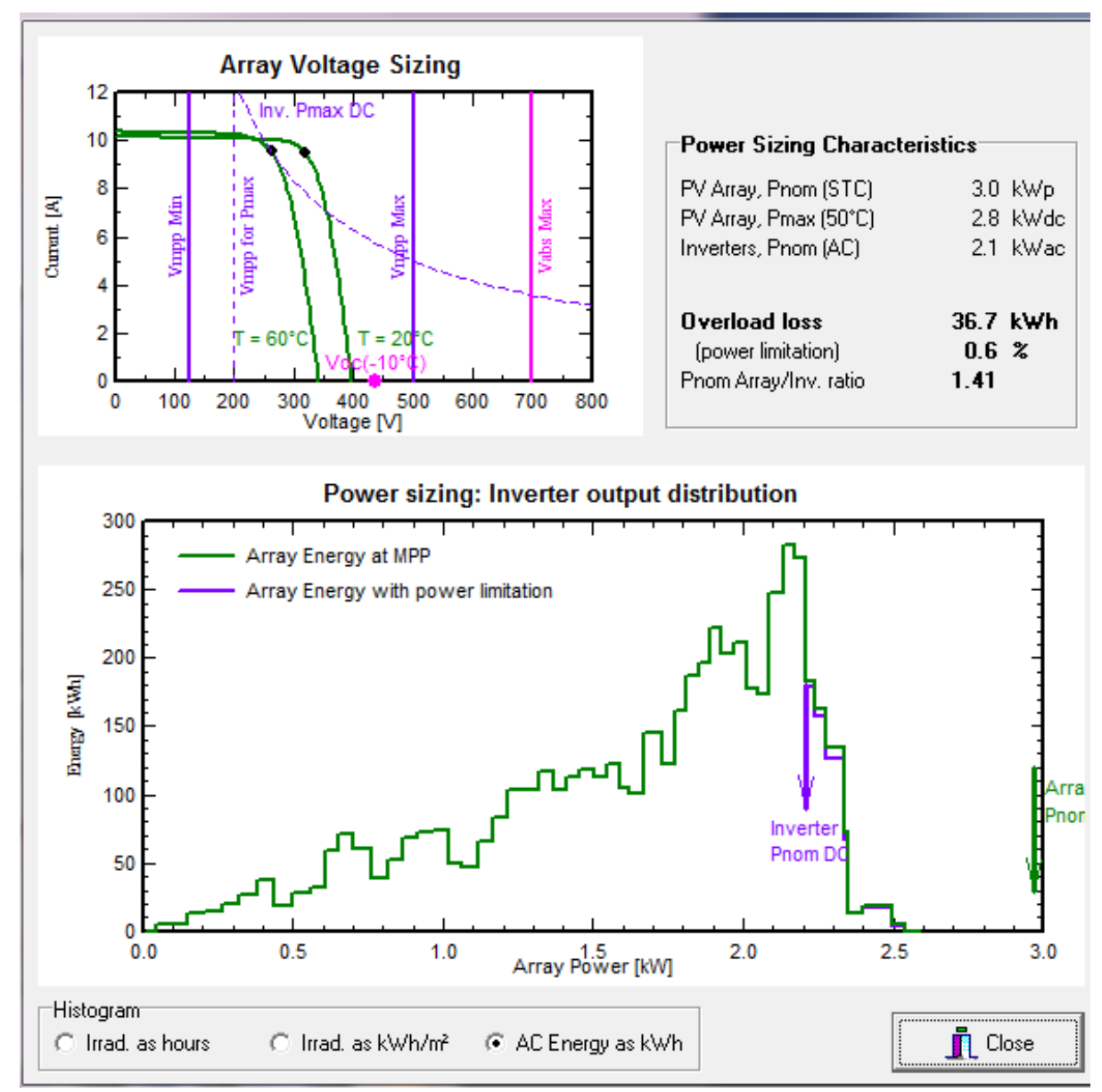

Fig. 3. The obtained MPP curve and inverter output distribution for the selected site 
It is evitable to study the solar behavior of the selected site in order to assess the performance of the proposed hybrid systems. In lieu to this, analysis of sun-earth angle, solar azimuth angle in particular, was performed through PVsyt. The effect of variation in solar azimuth angle on the selected tilted plane ( $30^{\circ}$ with respect to the horizontal) is shown in Fig. 4.

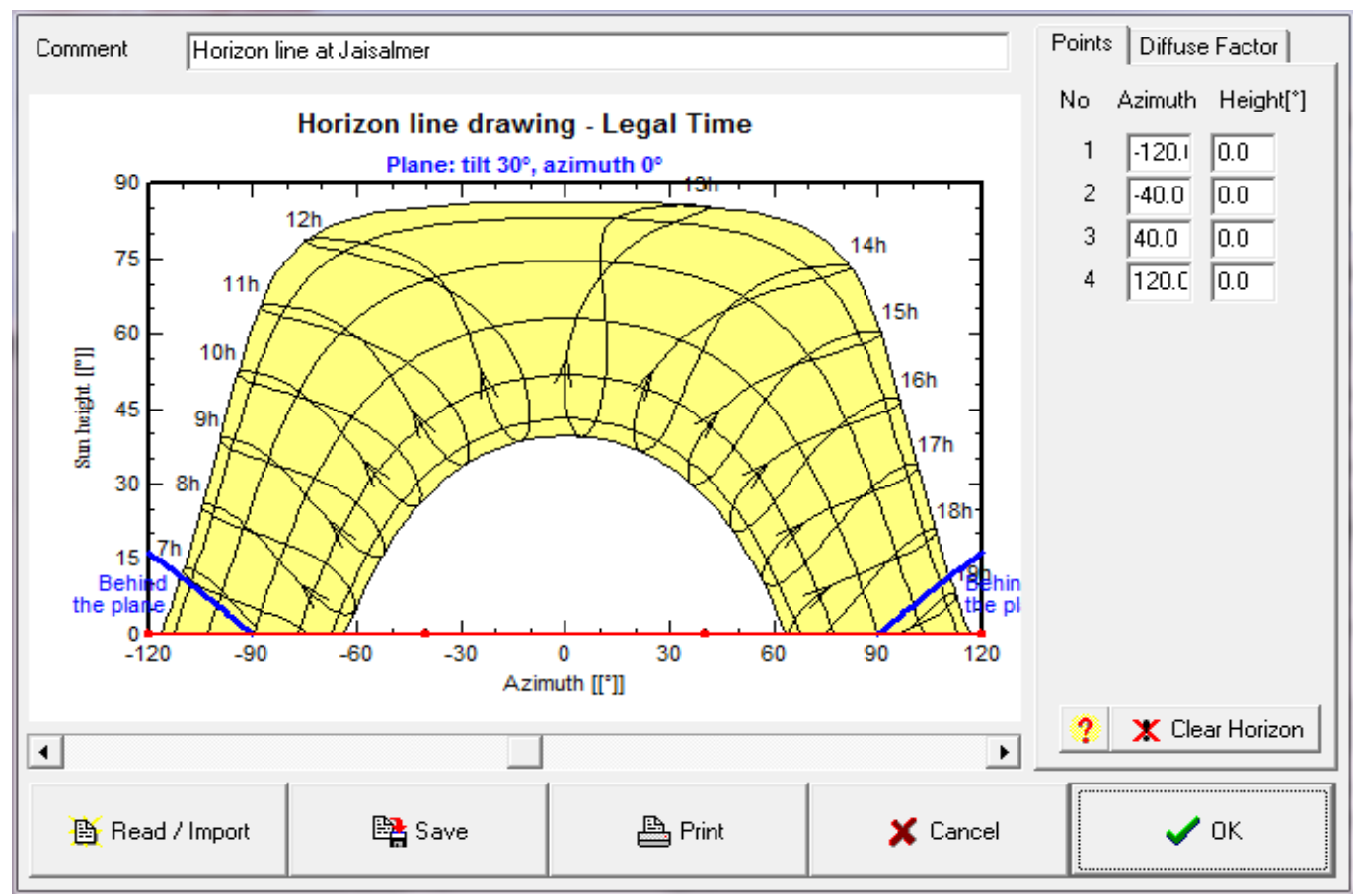

Fig. 4. The effect of variation in solar azimuth angle on the selected tilted plane

The obtained results for the selected site throw light on the annual variation behavior of the total received energy, global incidence, ambient temperature, effective global incidence, energy generated, grid-transfer, PV array efficiency and overall system efficiency. Table I below shows that annual global irradiance at Jaisalmer, Rajasthan varied from $115.3-219.4 \mathrm{kWh} / \mathrm{m}^{2}$. Table II represents the annual wind trends and global incidence data of the selected site (Jaisalmer). The obtained annual wind velocity trends would assist in designing an efficient and durable horizontal-axis wind turbine that is most suitable for the proposed hybrid system. The wind velocity varies through-out the year from $1.4-5.4 \mathrm{~m} / \mathrm{s}$ with an average value of $3.1 \mathrm{~m} / \mathrm{s}$.

Table I. Annual meteorological and incident data for Jaisalmer, Rajasthan

\begin{tabular}{|c|c|c|c|c|c|c|c|c|}
\hline & $\begin{array}{l}\text { GlobHor } \\
\text { kWh/m² }\end{array}$ & $\begin{array}{c}\mathbf{T} \text { Amb } \\
{ }^{\circ} \mathrm{C}\end{array}$ & $\begin{array}{l}\text { GlobInc } \\
\text { kWh/m }\end{array}$ & $\begin{array}{l}\text { GlobEff } \\
\mathbf{k W h} / \mathbf{m}^{2}\end{array}$ & $\begin{array}{c}\text { EArray } \\
\text { kWh }\end{array}$ & $\begin{array}{c}\text { E_Grid } \\
\text { kWh }\end{array}$ & $\begin{array}{c}\text { EffArrR } \\
\%\end{array}$ & $\begin{array}{c}\text { EffSysR } \\
\%\end{array}$ \\
\hline January & 126.4 & 16.39 & 184.1 & 180.1 & 460.5 & 444.8 & 10.31 & 9.96 \\
\hline February & 145.2 & 20.40 & 189.9 & 186.0 & 449.1 & 433.8 & 9.75 & 9.42 \\
\hline March & 184.5 & 26.48 & 211.5 & 206.6 & 493.1 & 476.0 & 9.61 & 9.28 \\
\hline April & 205.2 & 30.93 & 207.1 & 201.3 & 470.1 & 453.9 & 9.36 & 9.04 \\
\hline May & 219.4 & 34.61 & 201.7 & 195.2 & 455.4 & 439.8 & 9.31 & 8.99 \\
\hline June & 197.2 & 33.69 & 174.4 & 168.3 & 402.3 & 388.6 & 9.51 & 9.18 \\
\hline July & 186.4 & 32.18 & 168.5 & 162.6 & 394.1 & 380.6 & 9.64 & 9.13 \\
\hline August & 171.7 & 30.76 & 165.6 & 160.1 & 391.7 & 378.4 & 9.75 & 9.42 \\
\hline September & 171.3 & 30.59 & 184.8 & 179.8 & 429.1 & 414.5 & 9.57 & 9.24 \\
\hline October & 145.8 & 29.37 & 176.7 & 172.2 & 414.8 & 400.8 & 9.67 & 9.35 \\
\hline November & 131.2 & 23.45 & 183.1 & 179.4 & 437.5 & 422.2 & 9.85 & 9.50 \\
\hline December & 115.3 & 18.25 & 170.1 & 166.4 & 423.8 & 409.4 & 10.27 & 9.92 \\
\hline Year & 1999.5 & 27.29 & 2217.6 & 2158.0 & 5221.6 & 5042.8 & 9.71 & 9.37 \\
\hline
\end{tabular}


Table II. Annual wind and global incidence data for Jaisalmer, Rajasthan

\begin{tabular}{|c|c|c|c|c|c|c|c|c|}
\hline & $\begin{array}{c}\text { GlobHor } \\
\mathrm{kWh} / \mathrm{m}^{2}\end{array}$ & $\begin{array}{c}\text { DiffHor } \\
\mathrm{kWh} / \mathrm{m}^{2}\end{array}$ & $\begin{array}{c}\mathrm{T} \text { Amb } \\
{ }^{\circ} \mathrm{C}\end{array}$ & $\begin{array}{c}\text { WindVel } \\
\mathrm{m} / \mathrm{s}\end{array}$ & $\begin{array}{c}\text { GlobInc } \\
\mathrm{kWh} / \mathrm{m}^{2}\end{array}$ & $\begin{array}{c}\text { DifSInc } \\
\mathrm{kWh} / \mathrm{m}^{2}\end{array}$ & $\begin{array}{c}\text { Alb Inc } \\
\mathrm{kWh} / \mathrm{m}^{2}\end{array}$ & DifS/GI \\
\hline January & 126.4 & 37.26 & 16.39 & 1.7 & 184.1 & 48.57 & 1.694 & 0.000 \\
\hline February & 145.2 & 36.44 & 20.40 & 2.0 & 189.9 & 44.24 & 1.945 & 0.000 \\
\hline March & 184.5 & 61.93 & 26.48 & 2.1 & 211.5 & 68.92 & 2.472 & 0.000 \\
\hline April & 205.2 & 64.90 & 30.93 & 2.9 & 207.1 & 66.47 & 2.749 & 0.000 \\
\hline May & 219.4 & 85.50 & 34.61 & 5.0 & 201.7 & 81.87 & 2.936 & 0.000 \\
\hline June & 197.2 & 94.87 & 33.69 & 5.4 & 174.4 & 87.46 & 2.636 & 0.000 \\
\hline July & 186.4 & 96.17 & 32.18 & 5.1 & 168.5 & 89.36 & 2.496 & 0.000 \\
\hline August & 171.7 & 98.90 & 30.76 & 4.5 & 165.6 & 94.88 & 2.300 & 0.000 \\
\hline September & 171.3 & 73.89 & 30.59 & 3.4 & 184.8 & 77.14 & 2.295 & 0.000 \\
\hline October & 145.8 & 65.35 & 29.37 & 1.8 & 176.7 & 72.69 & 1.953 & 0.000 \\
\hline November & 131.2 & 38.15 & 23.45 & 1.4 & 183.1 & 47.79 & 1.758 & 0.000 \\
\hline December & 115.3 & 38.18 & 18.25 & 1.5 & 170.1 & 48.90 & 1.544 & 0.000 \\
\hline Year & 1999.5 & 791.53 & 27.29 & 3.1 & 2217.6 & 828.28 & 26.779 & 0.000 \\
\hline
\end{tabular}

The simulation conducted at Thapar Institute of Engineering and Technology, Patiala also caters to various losses pertaining to PV array Table III. The details for inverter losses in the proposed hybrid system are shown in Table IV. The various incurred PV losses are:

1. Wiring ohmic loss

2. Module quality loss

3. Module mismatch loss

4. Inverter loss

Table III. Annual system losses for the proposed system considering the selected site i.e. Jaisalmer

\begin{tabular}{|c|c|c|c|c|c|}
\hline & $\begin{array}{c}\text { ModQual } \\
\mathrm{kWh}\end{array}$ & $\begin{array}{c}\text { MisLoss } \\
\mathrm{kWh}\end{array}$ & $\begin{array}{c}\text { OhmLoss } \\
\mathrm{kWh}\end{array}$ & $\begin{array}{c}\text { EArrMPP } \\
\mathrm{kWh}\end{array}$ & $\begin{array}{c}\text { InvLoss } \\
\mathrm{kWh}\end{array}$ \\
\hline January & 7.186 & 4.718 & 5.472 & 461.7 & 16.84 \\
\hline February & 7.126 & 4.680 & 6.344 & 456.9 & 23.16 \\
\hline March & 7.706 & 5.060 & 6.753 & 494.2 & 18.26 \\
\hline April & 7.332 & 4.815 & 6.444 & 470.2 & 16.33 \\
\hline May & 7.092 & 4.657 & 5.632 & 455.4 & 15.62 \\
\hline June & 6.255 & 4.108 & 4.337 & 402.3 & 13.74 \\
\hline July & 6.125 & 4.022 & 4.067 & 394.1 & 13.50 \\
\hline August & 6.086 & 3.997 & 4.007 & 391.7 & 13.23 \\
\hline September & 6.682 & 4.388 & 5.302 & 429.1 & 14.56 \\
\hline October & 6.456 & 4.239 & 4.902 & 414.8 & 14.03 \\
\hline November & 6.829 & 4.484 & 5.756 & 438.2 & 16.00 \\
\hline December & 6.598 & 4.333 & 4.905 & 424.0 & 14.65 \\
\hline Year & 81.473 & 53.500 & 63.922 & 5232.7 & 189.99 \\
\hline
\end{tabular}


Table IV. Annual inverter losses for the proposed system considering the selected site i.e. Jaisalmer

\begin{tabular}{|c|c|c|c|c|c|c|c|c|}
\hline & $\begin{array}{c}\text { EOutInv } \\
\mathrm{kWh}\end{array}$ & $\begin{array}{c}\text { EffnvR } \\
\%\end{array}$ & $\begin{array}{c}\text { InvLoss } \\
\mathrm{kWh}\end{array}$ & $\begin{array}{c}\text { IL Oper } \\
\mathrm{kWh}\end{array}$ & $\begin{array}{c}\text { IL Pmin } \\
\mathrm{kWh}\end{array}$ & $\begin{array}{c}\text { IL Pmax } \\
\mathrm{kWh}\end{array}$ & $\begin{array}{c}\text { IL Vmin } \\
\mathrm{kWh}\end{array}$ & $\begin{array}{c}\text { IL Vmax } \\
\mathrm{kWh}\end{array}$ \\
\hline January & 444.8 & 96.6 & 16.84 & 15.65 & 0.000 & 1.191 & 0.000 & 0.000 \\
\hline February & 433.8 & 96.6 & 23.16 & 15.31 & 0.000 & 7.850 & 0.000 & 0.000 \\
\hline March & 476.0 & 96.5 & 18.26 & 17.11 & 0.000 & 1.152 & 0.000 & 0.000 \\
\hline April & 453.9 & 96.6 & 16.33 & 16.16 & 0.000 & 0.167 & 0.000 & 0.000 \\
\hline May & 439.8 & 96.6 & 15.62 & 15.62 & 0.000 & 0.000 & 0.000 & 0.000 \\
\hline June & 388.6 & 96.6 & 13.74 & 13.74 & 0.000 & 0.000 & 0.000 & 0.000 \\
\hline July & 380.6 & 96.6 & 13.50 & 13.50 & 0.000 & 0.000 & 0.000 & 0.000 \\
\hline August & 378.4 & 96.6 & 13.23 & 13.23 & 0.000 & 0.000 & 0.000 & 0.000 \\
\hline September & 414.5 & 96.6 & 14.56 & 14.56 & 0.000 & 0.000 & 0.000 & 0.000 \\
\hline October & 400.8 & 96.6 & 14.03 & 14.03 & 0.000 & 0.002 & 0.000 & 0.000 \\
\hline November & 422.2 & 96.5 & 16.00 & 15.23 & 0.000 & 0.770 & 0.000 & 0.000 \\
\hline December & 409.4 & 96.6 & 14.65 & 14.43 & 0.000 & 0.217 & 0.000 & 0.000 \\
\hline Year & 5042.8 & 96.6 & 189.99 & 178.57 & 0.000 & 11.349 & 0.000 & 0.000 \\
\hline
\end{tabular}

The simulation also details about the enhancement in energy harnessing by mounting PV array module around the stem of a horizontal-axis wind turbine. The annual energy need enhancement is projected in Table 5.

Table V. Annual Energy Needs for the proposed system considering the selected site i.e. Jaisalmer

\begin{tabular}{|c|c|}
\hline & E_Grid kWh \\
\hline January & 444.8 \\
\hline February & 433.8 \\
\hline March & 476.0 \\
\hline April & 453.9 \\
\hline May & 439.8 \\
\hline June & 388.6 \\
\hline July & 380.6 \\
\hline August & 378.4 \\
\hline September & 414.5 \\
\hline October & 400.8 \\
\hline November & 422.2 \\
\hline December & 409.4 \\
\hline Year & 5042.8 \\
\hline
\end{tabular}

\section{Conclusion}

The proposed solar PV-wind hybrid system with site location of Jaisalmer, Rajasthan is a feasible fit due to availability of both solar and wind energy. A simulation was conducted by inserting fixed variable inputs to assess the technical feasibility of the overall system. The simulation results as mentioned in the preceding sections were found to be within the acceptable limits.

The obtained results would pave a way forward towards developing a more sustainable, effective and rugged hybrid renewable energy systems that could cater the energy needs of the Indian sub-continent and similar geographical locations.

\section{VI.CONFLICT OF INTEREST}

The authors of the presented manuscript have contributed significantly in the research work and hereby declare no conflict of interest. The authors mutually agree on the order of name of authors for the presented manuscript. 


\section{REFERENCES}

[1] A. Adejumobi, S.G. Oyagbinrin, F. G. Akinboro \& M.B. Olajide, "Hybrid Solar and Wind Power: An Essential for Information Communication Technology Infrastructure and people in rural communities”, IJRRAS, Volume 9 (1), pp 130-138, October 2011.

[2] Kavita Sharma, Prateek Haksar "Designing of Hybrid Power Generation System using Wind Energy- Photovoltaic Solar EnergySolar Energy with Nanoantenna” Internationa Journal of Engineering Research And Applications (IJERA) Vol. 2 (1), pp.812-815, January-February 2012.

[3] Sandeep Kumar, Vijay Kumar Garg, “A Hybrid model of Solar-Wind Power Generation System”, International Journal of Advanced Research in Electrical, Electronics and Instrumentation Engineering (IJAREEIE), Vol. 2 (8), pp. 4107-4016, August 2013.

[4] Yandra Shivrath, P. Badari Narayana, Srikanth Thirumalasetty, Dr.E.Laxmi Narsaiah, "Design \& Integration of Wind-Solar Hybrid Energy System for Drip Irrigation Pumping Application”, International Journal of Modern Engineering Research (IJMER), Vol.2 (4), pp-2947-2950, July-August 2012.

[5] Arjun A. K., Athul S., Mohamed Ayub, Neethu Ramesh, and Anith Krishnan, "Micro-Hybrid Power Systems - A Feasibility Study", Journal of Clean Energy Technologies, Vol. 1, No. 1, pp 27-32, January 2013.

[6] J.B.V.Subrahmanyam, P.K.Sahoo and Madhukarreddy, 'Local PV-Wind hybrid systems development for supplying electricity to industry', Acta Electrotechnica, Vol.53, No.1, pp 10-15, 2012.

[7] N.Sivaramakrishna \& Ch.Kasi Ramakrishna Reddy, "Hybrid Power Generation through combined solar -Wind power and modified solar panel” International Journal of Engineering Trends and Technology (IJETT) - Volume4 (5), pp 1414-1417, May 2013.

[8] Yashwant Sawle, S.C. Gupta, Aashish Kumar Bohre \& Wei Meng PV-wind hybrid system: A review with case study, Cogent Engineering, 3:1, DOI: 10.1080/23311916.2016.1189305, 2016.

[9] Sirengo Khisa, R Ebihara, Tsutomu Dei, "Dynamics of a grid connected hybrid wind-solar and battery system: case study in NaivashaKenya”, Energy Procedia, Vol. 138, pp 680-685, 2017.

\section{AUTHOR PROFILE}

Dr. Parag Nijhawan is presently Assistant Professor in the Electrical and Instrumentation Engineering Department at Thapar Institute of Engineering and Technology, India. He received his B.E. and M.E. degrees in Electrical Engineering from the Punjab Technical University and Punjab Engineering College in India, respectively. He did his PhD. in Electrical Engineering from National Institute of Technology, Kurukshetra. He has more than 18 years of work experience that includes teaching and research. His research focus includes renewable energy sources, power quality improvement, grounding and FACTS devices.

Dr. Amandeep Singh Oberoi is presently Assistant Professor in the Mechanical Engineering Department at Thapar Institute of Engineering and Technology, India. He received his B.S. and M.S. degrees in Mechanical Engineering from the Punjab Technical University in India and his PhD. in Mechanical and Manufacturing Engineering from the Royal Melbourne Institute of Technology (RMIT) University in Melbourne, Australia. He has more than 10 years of work experience that includes working in industry, teaching and research. His research focus includes renewable energy sources, alternate fuels, solid-state hydrogen storage, proton electrolyte membrane fuel cells (PEMFCs), materials for energy storage, heat exchangers and heat sinks.

Dr. Baljit Singh is a Faculty of Mechanical Engineering at Universiti Teknology Mara (UiTM), Shah Alam, Selangor, Malaysia. He received his $\mathrm{PhD}$. in Mechanical and Manufacturing Engineering from the Royal Melbourne Institute of Technology (RMIT) University in Melbourne, Australia. He has more than 10 years of work experience that includes teaching and research. His research focus includes renewable energy sources, solar energy, solar pond, thermo-electric generators, and other alternate energy sources. 